\title{
Perspectives of intrauterine artificial insemination applicability in gilts
}

\author{
Kelly Jaqueline Will ${ }^{\text {(iD }}$ Ana Paula Gonçalves Mellagi' ${ }^{\text {iD }}$ Mari Lourdes Bernardi $^{2}$ iD \\ Fernando Pandolfo Bortolozzo ${ }^{1}$ (i) Rafael da Rosa Ulguim $^{1^{*}}$ (iD)
}

\begin{abstract}
${ }^{1}$ Setor de Suínos, Faculdade de Veterinária, Universidade Federal do Rio Grande do Sul (UFRGS), 90540-000, Porto Alegre, RS, Brasil. E-mail: rafael.ulguim@ufrgs.br. "Corresponding author.

${ }^{2}$ Departamento de Zootecnia, Faculdade de Agronomia, Universidade Federal do Rio Grande do Sul (UFRGS), Porto Alegre, RS, Brasil.

ABSTRACT: The application of the intrauterine artificial insemination (IUAI) technique allows optimization of a swine production system due to the reductions in volume and number of sperm cells in the insemination dose, and by reducing the time taken to perform the insemination. However, IUAI is not recommended for gilts due to the difficulty of intrauterine cannula passage through the cervix. This difficulty is associated mainly with the fact that the reproductive tract is smaller in gilts than in pluriparous females. However, few studies have evaluated the application of IUAI in gilts. In these studies, there are variations in approach concerning the definition of the success rate for cannula passage through the cervix, the type of cannula and the body characteristics of the gilts used, making it difficult to extrapolate the recommendation for the use of IUAI in gilts. Considering the evidence that such characteristics influence or even determine the success of the application of IUAI, there is a necessity for an understanding of the influence of these factors in the improvement and later application of the technique. Gilts represent about 15-20\% of the breeding group, and the use of IUAI could optimize the processes of insemination on farms. The approach used in this review highlights the aspects that could aid in structuring further studies for improving IUAI in gilts, allowing its use on commercial farms.
\end{abstract}

Key words: post-cervical insemination, nulliparous, intrauterine cannula, cervix.

Perspectivas de aplicabilidade da inseminação artificial intrauterina em leitoas

RESUMO: A aplicação da técnica de inseminação artificial intrauterina (IAU) permitiu uma otimização do sistema de produção de suínos por possibilitar a redução do volume e número de células espermáticas na dose inseminante e, também, por diminuir o tempo de execução da inseminação. Porém, a IAU não tem sido recomendada para leitoas devido à dificuldade de passagem do cateter intrauterino através da cérvix. Essa dificuldade é associada principalmente ao menor tamanho do trato reprodutivo de leitoas se comparado ao das fêmeas pluríparas. Entretanto, ainda são poucos os estudos que avaliaram a aplicação de IAU em leitoas. Nesses estudos, existem variações quanto à definição da taxa de sucesso na inserção do cateter através da cérvix, ao tipo de cateter e, também, quanto às características corporais das matrizes utilizadas, dificultando extrapolações de recomendação do uso da IAU em leitoas. Considerando os indicios de que tais características podem influenciar ou, até mesmo, determinar o sucesso de aplicação da técnica, ainda há necessidade de compreender a influência desses fatores para que a técnica possa ser aprimorada e posteriormente aplicada. Leitoas representam cerca de 15 a $20 \%$ do grupo de cobertura e viabilizar a IAU nessa categoria pode otimizar os processos de inseminação nas granjas. A abordagem realizada nessa revisão traz aspectos que podem auxiliar na estruturação de futuros estudos para aprimorar a IAU em leitoas e permitir seu emprego em granjas comerciais.

Palavras-chave: inseminação pós-cervical, nulíparas, cateter intrauterino, cérvix.

\section{INTRODUCTION}

Artificial insemination (AI) is the mostused reproduction biotechnology in the swine industry (RIESENBECK, 2011; SORIANO-ÚBEDA et al., 2013; WABERSKI et al., 2019). Different methods have been developed over the years, but currently cervical artificial insemination (CAI) and intrauterine artificial insemination (IUAI) are used commercially.

In CAI, also known as traditional AI, a catheter of approximately $50-60 \mathrm{~cm}$ in length is placed in the posterior cervix and the insemination dose (ID) is deposited in the cervix's lumen (SORIANO-ÚBEDA et al., 2013; BORTOLOZZO et al., 2015; ROCA et al., 2016). For this technique, IDs containing 1.3-4 billion sperm cells (mostly $2.5-4$ billion) extended in a total volume of $70-100 \mathrm{~mL}$ are used depending on the region or country (SORIANO-ÚBEDA et al., 2013; BORTOLOZZO et al., 2015; KNOX, 2016; ROCA et al., 2016; WABERSKI et al., 2019). Considering that females are inseminated two or three times, a total of 2.6-12 billion sperm cells are used per estrus. 
Alternatively, the IUAI technique (also known as post-cervical artificial insemination PCAI), consists of using an inner cannula through the traditional catheter allowing ID deposition in the uterine lumen (after the cervix and before the uterine bifurcation) (WATSON \& BEHAN, 2002). Therefore, by reducing the sperm transit through the cervix, IUAI allows the use of IDs of lower volume and number of sperm cells than CAI without impairing reproductive performance (WATSON \& BEHAN, 2002; HERNÁNDEZ-CARAVACA et al., 2012). Thus, IDs with 1-2 billion sperm cells in a volume of $40-50 \mathrm{~mL}$ are used for IUAI (BORTOLOZZO et al., 2015; WABERSKI et al., 2019). The advantages of IUAI compared to CAI are reported to be the reduction in the number of sperm cells and the volume of IDs, allowing the production of a greater number of IDs per ejaculate and optimizing the use of boars of higher genetic index (WATSON \& BEHAN, 2002; DALLANORA et al., 2004; HERNÁNDEZ-CARAVACA et al., 2012; GARCÍA-VÁZQUEZ et al., 2019b), shorter time to perform the insemination (MARTINEZ et al., 2002; WATSON \& BEHAN, 2002), and a reduction in the costs of boar acquisition and maintenance (DIEHL et al., 2006). IUAI is consolidated and has been applied successfully to more than $90 \%$ of pluriparous sows (WATSON \& BEHAN, 2002; DALLANORA et al., 2004; MEZALIRA et al., 2005; BENNEMANN et al., 2007), to approximately $86 \%$ of primiparous sows (SBARDELLA et al., 2014) and is widespread in the production systems for these categories.

Despite that, there are limitations to recommending IUAI in gilts, the most significant challenge being the difficulty of cannula insertion through the cervix (HERNÁNDEZ-CARAVACA et al., 2017; GARCÍA-VÁZQUEZ et al., 2019b). Thus, there is still a need to perform both AI techniques (CAI and IUAI) in the farm routine and to produce two semen dose sizes in the boar studs (BORTOLOZZO et al., 2015; GARCÍA-VÁZQUEZ et al., 2019b). Considering that gilts represent a significant number of animals in the breeding herd (BORTOLOZZO \& WENTZ, 2006), the use of IUAI could consolidate advantages observed in pluriparous sows and allow standardization of the AI technique used on farms and the semen dose production in boar studs.

This review discusses the main results obtained using IUAI in gilts, since its application is still a challenge for this category. Additionally, the factors that affect the reported results are discussed in order for it to be considered in future approaches for the improvement and use of the technique in gilts.
The use of intrauterine artificial insemination

HANCOCK (1959) made the first report of using a device for intrauterine semen deposition. However, scientific information on IUAI application under commercial conditions was reported only from 2002 (WATSON \& BEHAN, 2002). From that time, several studies to determine the number of sperm cells and the volume of IDs that provide satisfactory reproductive performance with IUAI have been conducted (DALLANORA et al., 2004; ROZEBOOM et al., 2004; MEZALIRA et al., 2005; BENNEMANN et al., 2007; ARAÚJO et al., 2009; HERNÁNDEZCARAVACA et al., 2012). IUAI came to be used in pluriparous sows, with doses containing about 1.5 billion sperm cells in a volume of $45-50 \mathrm{~mL}$. Although, there are no official data, Brazil stands out in the use of IUAI, with an estimated $60 \%$ of total inseminations performed by IUAI (WABERSKI et al., 2019) and more than $80 \%$ of farms using this technique in pluriparous sows (BORTOLOZZO, F.P.; personal information).

IUAI remains limited and nonrecommended for gilts (BORTOLOZZO et al., 2015; GARCÍA-VÁZQUEZ et al., 2019b), and few studies evaluating IUAI included gilts or primiparous sows. The explanation for this non-inclusion was based on the difficulty of cannula insertion through the cervix and occurrence of bleeding, which is higher in primiparous sows and gilts than in pluriparous sows (15-23\% versus 0-10\%) (DALLANORA et al., 2004; BENNEMANN et al., 2007; SBARDELLA et al., 2014; HERNÁNDEZ-CARAVACA et al., 2017; GARCÍA-VÁZQUEZ et al., 2019b). Additionally, when attempts at IUAI in gilts were made using a cannula for pluriparous sows, histological examination confirmed injuries to the cervical mucosa in most of the gilts (43/68) (BEHAN \& WATSON, 2006). This sum of factors determined the recommendation for IUIA use only for females with parity order (PO) of 2 or more. In fact, the first studies that included primiparous sows resulted in a reduction in the number of piglets born (SERRET et al., 2005) and difficulty with cannula insertion (DIEHL et al., 2006), indicating the necessity for adjustments in the technique according to the PO.

Some years later, after the standardization of the IUAI in PO $\geq 2$ sows, SBARDELLA et al. (2014) were the first to evaluate and validate IUAI specifically for primiparous sows. The authors reached a success rate of $86 \%$ in intrauterine cannula insertion in all inseminations. In the same study, no differences were observed in the reproductive performance when comparing IUAI (1.5 billion 
sperm cells in $45 \mathrm{~mL}$ ) with CAI (3.0 billion sperm cells in $90 \mathrm{~mL}$ ). Improvements over the years that have increased the success rate of IUAI in young females must be considered, such as the suggestion to remove contact with boars during IUAI to avoid the cervical contraction stimulation and its possible effect on the difficulty of cannula insertion (ULGUIM et al., 2018a); improvements in intrauterine cannulas (more flexible material); as well as greater experience by the operators (GARCÍA-VÁZQUEZ et al., 2019b). However, even with the knowledge of these factors and with the emergence of new intrauterine cannulas for gilts recently, there is still a necessity for additional studies to make the use of IUAI feasible in gilts.

\section{Intrauterine artificial insemination in gilts}

One of the first studies comparing the insemination techniques (CAI and IUAI) in gilts included 47 animals, and a higher total number of piglets born and born alive was observed for CAI compared to IUAI but no statistically significant difference (DIMITROV et al., 2007). In their study, the success rate of cannula insertion was not reported. As with primiparous sows, studies on IUAI in gilts were not conducted for several years. However, with the improvement in cannulas and standardization of the technique studies of IUAI in gilts were resumed.

Our understanding is that the necessity of deepening the knowledge of the factors associated with the success of IUAI in gilts should include an understanding of the best device to be used, the gilts' cervix characteristics and the methods applied during the attempts at intrauterine cannula insertion. Most of the IUAI attempts conducted in gilts under field conditions were performed initially with consolidated catheters and intrauterine cannulas for pluriparous sows.

In a recent study published exclusively on gilts, a low success rate of cannula insertion and gilts successfully inseminated by IUAI $(23 \%)$ was reported when a multi-ring catheter designed for pluriparous sows and a 3.5-mm-diameter intrauterine cannula were used (HERNÁNDEZ-CARAVACA et al., 2017). Under field conditions, ULGUIM et al. (2018b) measured the success rate and insertion depth of an intrauterine cannula $(75-\mathrm{cm}$ length and $3.5-\mathrm{mm}$ diameter) in the first insemination, when catheters designed for either pluriparous sows or gilts were used as guides for cannula insertion. A cannula insertion of more than $10 \mathrm{~cm}$ was possible in $44 \%$ of gilts using catheters designed for either pluriparous sows or gilts. In contrast, a higher percentage of gilts with cannula insertion of less than $6 \mathrm{~cm}$ was observed using a catheter designed for gilts (40\%) when compared to a catheter used for pluriparous sows (28\%). Results suggested a better fixation in the cervix with the catheter used for pluriparous sows, facilitating the manipulation of the intrauterine cannula through the cervix and its use as a guide for IUAI in gilts. In a recent study conducted by our group (unpublished data), no difference in the success rate for intrauterine cannula insertion $(\sim 70 \%)$ was observed when guide catheters for pluriparous sows with different tip shapes (foam-tip or spiral-tip) were used. However, the spiraltip catheter resulted in a greater semen backflow and number of attempts required for cannula insertion than did the foam-tip catheter.

On the other hand, even with some degree of difficulty in $42 \%$ of the gilts, a success rate close to that observed in pluriparous sows for cannula insertion was reported in gilts $(91 \%)$ by TERNUS et al. (2017). In some studies, the approach used to define the success rate or percentage of cannula insertion is unclear because the methodological description is often unclear. This is because the insertion percentage can consider the percentage of gilts in which cannula insertion was possible in all inseminations during the estrus, the percentage of gilts that received at least one IUAI during the estrus, or the percentage of inseminations where the intrauterine cannula insertion was possible per total number of inseminations performed. Additionally, the lack of information on the devices' dimensions makes it difficult to identify those with the greatest potential for applicability in IUAI. Also, there is a lack of information about the number of attempts made and time required for cannula insertion, as well as the gilts' characteristics at insemination (age, weight, body condition score, and the number of previous estrus detected), making it difficult to draw conclusions about the possibilities of using IUAI in gilts.

The use of substances for cervix dilation and the development of devices specifically designed for IUAI in gilts are strategies used to overcome the difficulties of cannula insertion through the cervix. Drugs for cervix dilation have been successfully used in ewes, in which there is also difficulty in catheter insertion through the cervix for transcervical insemination (ROBINSON et al., 2011). In this way, according to HERNÁNDEZ-CARAVACA et al. (2017), when vetrabutin chlorhydrate was injected intramuscularly and compared to the cervical deposition of warm extender for cervix relaxation, no significant improvement in the success rate for IUAI in gilts was observed ( $34 \%$ and $24 \%$, respectively); however, this approach is uncommon in pigs. Regarding the use of a specific device designed for 
gilts (16-mm-diameter catheter and 2.5-mm-diameter intrauterine cannula), the success rate was higher (60\% versus 37\%) compared to the use of the same catheter $(16 \mathrm{~mm})$ with a larger-diameter cannula (3.5 mm) (HERNÁNDEZ-CARAVACA et al., 2017). Similarly, SUÁREZ-USBECK et al. (2019) observed that the insertion of the cannula was possible in $77.5 \%$ of gilts when a catheter and a cannula specifically designed for gilts were used. Recent results using a cannula specific for gilts (3.0-mm diameter) also indicated percentages close to $60 \%$ of gilts in which cannula insertion was possible in all inseminations performed during estrus (WILL et al., 2021). Considering that the cannula diameter can influence the IUAI success rate, adjustments to the device have been the most-used strategies, showing promising results for the progress of the technique.

In general, in different studies in which IUAI was evaluated in gilts, the reproductive performance was not affected compared to CAI (Table 1). In another approach, LLAMAS-LÓPEZ et al. (2019) used a cannula specially designed for gilts for deposition of the ID at $8 \mathrm{~cm}$ further cranially than the conventional catheter. This technique was considered deep cervical artificial insemination (DpCAI), indicating an alternative to IUAI and CAI. The technique ( 1.5 billion sperm cells per ID) was successfully performed in $89 \%$ of the gilts and there were no differences in reproductive performance compared to CAI (2.5 billion sperm cells per ID). However, the authors reported that the ID was infused slowly due to cervical deposition. Therefore, DpCAI could be an interesting strategy, but it would not include the benefit of reduction in the time for semen dose infusion (an important advantage of IUAI). Additionally, in a recent study conducted by our research group, we observed good reproductive results, even using CAI with reduced number of sperm cells (WILL et al., 2021). However, additional care is required during insemination using this technique. In this sense, the Dp-CAI can bring more security than CAI, with a reduced number of sperm cells, but does not benefit from the full advantages of IUAI.

Characteristics to be considered in the use of IUAI in gilts

The smaller dimensions of the reproductive tract are the reason for the difficulty

Table 1 - Reproductive performance using intrauterine artificial insemination (IUAI) with different numbers of sperm cells and insemination dose (ID) volumes in gilts.

\begin{tabular}{|c|c|c|c|c|c|c|c|c|}
\hline Reference & $\mathrm{n}^{1}$ & $\begin{array}{c}\text { AI } \\
\text { technique }\end{array}$ & $\begin{array}{c}\text { Catheter }+ \\
\text { cannula type }^{2}\end{array}$ & $\begin{array}{l}\text { No. of sperm } \\
\text { cells }\left(\times 10^{9}\right)^{3}\end{array}$ & $\begin{array}{l}\text { Vol. } \\
(\mathrm{mL})^{4}\end{array}$ & $\begin{array}{l}\text { Farrowing } \\
\text { rate }(\%)\end{array}$ & $\mathrm{TPB}^{5}$ & $\mathrm{SR}^{6}(\%)$ \\
\hline \multirow{2}{*}{$\begin{array}{l}\text { DIMITROV et al. } \\
(2007)\end{array}$} & 28 & $\mathrm{CAI}^{7}$ & - & 3.0 & 100 & 85.7 & 10.3 & - \\
\hline & 19 & IUAI $^{8}$ & $-+\mathrm{P}$ & 1.5 & 50 & 89.5 & 9.1 & - \\
\hline \multirow{4}{*}{$\begin{array}{l}\text { HERNÁNDEZ- } \\
\text { CARAVACA et al. } \\
\text { (2017) }\end{array}$} & 47 & CAI & - & 3.0 & 80 & 93.6 & 13.7 & - \\
\hline & 56 & IUAI & $\mathrm{P}+\mathrm{P}$ & 1.5 & 40 & 82.6 & 13.1 & 19.6 \\
\hline & 54 & IUAI & $\mathrm{G}+\mathrm{P}$ & 1.5 & 40 & 93.3 & 13.2 & 37.0 \\
\hline & 63 & IUAI & $\mathrm{G}+\mathrm{G}$ & 1.5 & 40 & 84.3 & 13.9 & 60.3 \\
\hline \multirow{2}{*}{ TERNUS et al. (2017) } & 273 & CAI & - & 2.5 & 80 & 89.4 & 11.6 & - \\
\hline & 279 & IUAI & - & 1.5 & 40 & 91.8 & 11.8 & 91.4 \\
\hline \multirow{2}{*}{$\begin{array}{l}\text { SUÁREZ-USBECK et } \\
\text { al. (2019) }\end{array}$} & 324 & CAI & - & 3.0 & 90 & 85.8 & 18.3 & - \\
\hline & 248 & IUAI & $\mathrm{G}+\mathrm{G}$ & 1.5 & 45 & 88.7 & 18.5 & 77.5 \\
\hline \multirow{2}{*}{$\begin{array}{l}\text { LLAMAS-LÓPEZ et al. } \\
\text { (2019) }\end{array}$} & 130 & CAI & - & 2.5 & 85 & 83.6 & 13.7 & - \\
\hline & $\begin{array}{c}103 \\
6\end{array}$ & $\mathrm{Dp}-\mathrm{CAI}^{9}$ & $\mathrm{G}+\mathrm{G}$ & 1.5 & 45 & 87.5 & 13.1 & 88.9 \\
\hline \multirow{4}{*}{ WILL et al. (2021) } & 158 & CAI & - & 1.5 & 50 & 93.7 & 14.5 & \multirow{2}{*}{-} \\
\hline & 159 & CAI & - & 2.5 & 80 & 95.6 & 14.5 & \\
\hline & 90 & IUAI & $P+G$ & 1.5 & 50 & 94.4 & 14.8 & \multirow{2}{*}{58.9} \\
\hline & 97 & IUAI & $P+G$ & 2.5 & 80 & 93.8 & 14.5 & \\
\hline
\end{tabular}

${ }^{1}$ Number of inseminated gilts; ${ }^{2}$ Catheter for cervical fixation used for pluriparous sows (P) or gilts $(\mathrm{G})+$ intrauterine cannula for pluriparous sows (P) or gilts (G); ${ }^{3}$ Number of sperm cells in the ID $\left(\times 10^{9}\right) ;{ }^{4}$ ID volume; ${ }^{5} \mathrm{TPB}-$ total number of piglets born; ${ }^{6} \mathrm{SR}-$ success rate of intrauterine cannula insertion; ${ }^{7} \mathrm{CAI}$ - cervical artificial insemination; ${ }^{8} \mathrm{IUAI}-$ intrauterine artificial insemination; ${ }^{9} \mathrm{Dp}$ CAI - deep cervical artificial insemination. There was no difference between treatments in any study. 
of intrauterine cannula insertion through the cervix (KAPELAŃSKI et al., 2013; TUMMARUK \& KESDANGSAKONWUT, 2014). In this way, recently, GARCÍA-VÁZQUEZ et al. (2019a) characterized the reproductive tract morphometry of the parts involved in the IUAI of pluriparous sows (PO $\geq 5$, and $234.05 \pm 11.71 \mathrm{~kg}$ average weight) and gilts ( 220 days of age, and $165.76 \pm 8.5 \mathrm{~kg})$. Compared to gilts, pluriparous sows presented longer vagina + cervix length $(56.23 \pm 6.01$ versus $50.39 \pm$ $5.25 \mathrm{~cm})$, larger cervix length $(25.93 \pm 4.64$ versus $21.65 \pm 3.39 \mathrm{~cm}$ ), and larger perimeter and area in the uterine part of the cervix $(8.50 \pm 1.44 \mathrm{~cm}$ and $4.07 \pm 1.46 \mathrm{~cm}^{2}$; versus $6.28 \pm 0.92 \mathrm{~cm}$ and $2.46 \pm$ $0.56 \mathrm{~cm}^{2}$ ), all respectively. Additionally, pluriparous sows had more connective tissue $(67.60 \pm 13.38$ versus $58.86 \pm 10.78 \%$ ) and fewer muscle fibers $(30.66 \pm 13.69$ versus $39.79 \pm 10.24 \%)$ than gilts, respectively. These differences in connective tissue and muscle fiber content could explain the lower distension capacity of the gilt cervix, which may make intrauterine cannula insertion difficult. Also, the gilts had a higher density of cervical ridges in the uterine part of the cervix, which reduced the cervical lumen and made cannula insertion more restricted. Therefore, new devices for IUAI must consider the morphological peculiarities of the gilt cervix.

Specific characteristics of the different genetic lines represent also factors to be considered, as suggested by the results of TERNUS et al. (2017), who observed a high percentage of cannula insertion in their study. Another point is related to the effect of age and weight of gilts on the success rate. SUÁREZ-USBECK et al. (2019) used gilts of 150 $\pm 5 \mathrm{~kg}$, at least two previously detected estrus, and 255-270 days of age at insemination (older than is normally recommended for the first insemination). Although, the influence of these factors on the percentage of gilts that allowed cannula insertion was not evaluated, the good results concerning cannula insertion indicated that IUAI success is greater in older or heavier gilts. Despite the authors crediting the success of cannula insertion to the use of a cannula specific for gilts, the possible effects of age and weight should not be excluded.

In a study from the 1980s it was reported that larger cervix dimensions (weight and length) were associated with heavier, older, and cyclical gilts (females with ovarian structures characteristic of previous reproductive cycles) (PRUNIER et al., 1987). Similarly, TUMMARUK and KESDANGSAKONWUT (2014) observed larger dimensions of the reproductive tract in cyclical females compared to non-cyclical, and greater length of the uterus in gilts of higher body weight $(\geq 161 \mathrm{~kg})$. In this way, recently, WILL et al. (2021) observed that gilts of $\geq 225$ days old at insemination and weighing $\geq 124 \mathrm{~kg}$ in the estrus previous to the insemination estrus had a higher success rate of intrauterine cannula insertion than those of lower weight and age. Here, the success rate considered the cannula insertion through the cervix in all inseminations performed during estrus. Additionally, in a recent evaluation performed by our group, we observed a tendency $(\mathrm{P} \leq 0.10)$ of an interaction effect between classes of weight, body condition score (BCS), and caliper unit, with different classes of age, where gilts of older age, higher weight, and higher body condition parameters (BCS and caliper) showed a higher success rate of cannula insertion than those of lower age, weight and body condition score (Table 2). These results suggested that these factors combined influence the percentage success of cannula insertion through the cervix in gilts and should be better explored in future studies.

Considering the above discussion concerning the characteristics of the gilts at first insemination, it is important to remember that a certain degree of body and physiological development is necessary to achieve puberty, which is usually reached at approximately 150 220 days of age and is defined as the occurrence of the first estrus and subsequent regular cyclicity at intervals of 18-24 days (MELLAGI et al., 2006; SOEDE et al., 2011). The first insemination is recommended from the second detected estrus when the gilts reach 135-150 kg body weight, avoiding compromising the farrowing rate and litter size (KUMMER et al., 2005; BORTOLOZZO et al., 2009). However, the recommendations range from 203-240 days of age and $135-160 \mathrm{~kg}$ body weight, according to genetic line.

Therefore, the variations in intrauterine cannula insertion rates among studies may be related to the different characteristics of the gilts used (weight, age, number of previous estrus detected), which are possibly associated with the dimensions of the reproductive tract. In this way, due to differences in the age and weight recommendations for the first insemination, and in the physical conformation of gilts, scientific information that considers the cannula insertion in different genetic lines are required. These characteristics are relatively easy to measure in the farm's routine and an understanding of their effects can be essential before recommending IUAI in gilts. 
Table 2 - Success rate (\%) of intrauterine cannula insertion through the cervix of gilts according to different classes of age, body condition score (BCS), caliper unit and weight.

\begin{tabular}{|c|c|c|c|c|c|c|c|}
\hline \multirow[t]{2}{*}{ Classes $^{1}$} & \multirow[t]{2}{*}{$\mathrm{n}$} & \multicolumn{3}{|c|}{ 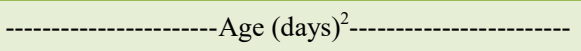 } & \multicolumn{3}{|c|}{ 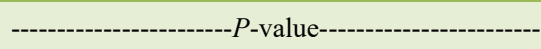 } \\
\hline & & $\leq 224$ & $225-241$ & $\geq 242$ & Age & Class 1 & Age $\times$ Class \\
\hline $\mathrm{n}$ & & 80 & 157 & 82 & & & \\
\hline $\mathrm{BCS}^{2}$ & & & & & $<0.01$ & 0.27 & 0.09 \\
\hline 2.5 & 65 & $36.8^{\text {by }}$ & $60.6^{\text {by }}$ & $61.5^{\text {by }}$ & & & \\
\hline 3 & 177 & $53.1^{\text {by }}$ & $57.0^{\text {by }}$ & $54.8^{\text {by }}$ & & & \\
\hline$>3$ & 77 & $33.3^{\text {by }}$ & $71.1^{\mathrm{bx}}$ & $88.9^{\text {ax }}$ & & & \\
\hline Caliper $^{2}$ & & & & & 0.01 & 0.34 & 0.10 \\
\hline$<13$ & 68 & $52.4^{\mathrm{bx}}$ & $55.9^{\mathrm{bx}}$ & $61.5^{\mathrm{bx}}$ & & & \\
\hline $13-14$ & 170 & $47.7^{\mathrm{bx}}$ & $60.2^{\mathrm{bx}}$ & $55.8^{\mathrm{bx}}$ & & & \\
\hline$>14$ & 81 & $33.3^{\mathrm{bz}}$ & $67.5^{\text {by }}$ & $88.5^{\mathrm{ax}}$ & & & \\
\hline Weight $(\mathrm{kg})^{3}$ & & & & & 0.01 & 0.04 & 0.06 \\
\hline$<124$ & 78 & $36.7^{b x}$ & $50.0^{\mathrm{bx}}$ & $42.9^{b x}$ & & & \\
\hline $124-140$ & 162 & $60.5^{\mathrm{ax}}$ & $59.6^{\mathrm{bx}}$ & $62.9^{\mathrm{ax}}$ & & & \\
\hline$>140$ & 79 & $25.0^{\text {by }}$ & $76.5^{\mathrm{ax}}$ & $81.8^{\mathrm{ax}}$ & & & \\
\hline
\end{tabular}

1 Class of body variable; 2 Data on the variables age, BCS and caliper unit were recorded at the moment of insemination (2nd estrus); 3 The weight variable was measured at the estrus previous to the insemination estrus. In this study, the success rate was defined as the percentage of gilts that allowed intrauterine cannula insertion through the cervix in all inseminations performed during estrus. The effect of interaction was considered as a tendency $(0.05<P \leq 0.10)$; $\mathrm{a}-\mathrm{b}$ in the same column indicates tendency to difference between the classes of body variables. $x-z$ in the same row indicates tendency to difference between the age classes (unpublished data).

In summary, it has been reported in most studies, as well as by production system operators, that the greatest challenge to the use of IUAI on a large scale is the difficulty of cannula insertion through the cervix, and consequently the longer time required to perform the technique. Thus, despite the good results obtained recently in gilts, IUAI has not been used in most production systems (GARCÍA-VÁZQUEZ et al., 2019b). For this reason, improvements to the technique, considering the factors that could influence or even determine the success of IUAI in gilts, are necessary before making a recommendation for its use on a commercial scale.

\section{CONCLUSION}

The few studies that have evaluated IUAI and included gilts used different approaches to define the success of cannula insertion. The characteristics of the gilts at first insemination and the catheters and cannulas used for IUAI are different between studies. These considerations make it difficult to conclude a recommendation concerning IUAI in gilts. We considered that the technique remains limited to gilts, even with a success rate close to $70 \%$, due to the difficulty of cannula insertion through the cervix. Future studies should focus on a better understanding of the possible effects of genetic factors and the physical characteristics of gilts on the success rate of cannula insertion.

\section{ACKNOWLEDGMENTS}

This study was financed in part by the Coordenação de Aperfeiçoamento de Pessoal de Nível Superior - Brasil (CAPES) - Finance Code 001

\section{DECLARATION OF CONFLICTS OF} INTERESTS

The authors declare no conflict of interest. The founding sponsors had no role in the design of the study; in the collection, analyses, or interpretation of data; in the writing of the manuscript, and in the decision to publish the results.

\section{AUTHORS' CONTRIBUTIONS}

The authors contributed equally for the manuscript.

\section{REFERENCES}

ARAÚJO, É. B. et al. Reproductive performance of sows submitted to intrauterine insemination. Revista Brasileira de Zootecnia, v.38, n.8, p.1460-1467, 2009. Available from: $<$ http:// dx.doi.org/10.1590/S1516-35982009000800009>. Accessed: Dec. 15, 2019. doi: 10.1590/S1516-35982009000800009.

BEHAN, J.; P. WATSON. A field investigation of intracervical insemination with reduced sperm numbers in gilts. Theriogenology, v.66, n.2, p.338-343, 2006. Available from: $\quad<$ https://www.sciencedirect.com/science/article/abs/pii/ S0093691X05005248?via\%3Dihub>. Accessed: May, 02, 2020. doi: 10.1016/j.theriogenology.2005.11.020. 
BENNEMANN, P. E. et al. Reproductive performance of sows submitted to intrauterine or tradicional artificial insemination. Ciência Rural, v.37, n.6, p.1735-1739, 2007. Available from: <http://dx.doi.org/10.1590/S0103-84782007000600036>. Accessed: Jan. 15, 2020. doi: 10.1590/S0103-84782007000600036.

BORTOLOZZO, F. et al. Growth, body state and breeding performance in gilts and primiparous sows. In: H. RodriguezMartinez, J. Vallet, et al (Ed.). Control of Pig Reproduction VIII. Alberta: Nottingham University Press, 2009. p.281-291.

BORTOLOZZO, F. et al. New artificial insemination technologies for swine. Reproduction in Domestic Animals, v.50, p.80-84, 2015. Available from: <https://doi.org/10.1111/rda.12544>. Accessed: May, 06, 2020. doi: 10.1111/rda.12544.

BORTOLOZZO, F.; I. WENTZ. Importância das leitoas no sistema de produção de suínos. In: F. P. Bortolozzo e I. Wentz (Ed.). Suinocultura em ação: A fêmea suína de reposição. Porto Alegre: Palotti, 2006. p.15-21.

DALLANORA, D. et al. Reproductive performance of swine females inseminated by intrauterine or traditional technique. Pesquisa Agropecuária Brasileira, v.39, n.8, p.815-819, 2004. Available from: <http://dx.doi.org/10.1590/S0100204X2004000800013>. Accessed: May, 07, 2020. doi: 10.1590/ S0100-204X2004000800013.

DIEHL, G. N. et al. New pipette for intrauterine insemination in pigs. Ciência Rural, v.36, n.1, p.179-185, 2006. Available from: <http://dx.doi.org/10.1590/S0103-84782006000100027>. Accessed: Jan. 21, 2020. doi: 10.1590/S0103-84782006000100027.

DIMITROV, S. et al. Deep intrauterine and transcervical insemination of sows and gilts. Trakia Journal of Sciences, v.5, n.1, p.40-46, 2007. Available from: <http://tru.uni-sz. bg/tsj/Vol5N1 2007/Dimitrov\%20et\%20al.pdf>. Accessed: May, 07, 2020.

GARCÍA-VÁZQUEZ, F. et al. Morphological changes in the porcine cervix: A comparison between nulliparous and multiparous sows with regard to post-cervical artificial insemination. Theriogenology, v.127,p.120-129,2019a.Available from: $<$ https:// doi.org/10.1016/j.theriogenology.2019.01.004>. Accessed: Jan. 10, 2020. doi: 10.1016/j.theriogenology.2019.01.004.

GARCÍA-VÁZQUEZ, F. et al. Post-cervical artificial insemination in porcine: The technique that came to stay. Theriogenology, v.129, p.37-45, 2019b. Available from: <https://www.sciencedirect. com/science/article/abs/pii/S0093691X18303327?via\%3Dihub>. Accessed: Apr. 29, 2020. doi: https://doi.org/10.1016/j. theriogenology.2019.02.004.

HANCOCK, J. L. Pig insemination technique. Veterinary Record, v.71, p.527, 1959.

HERNÁNDEZ-CARAVACA, I. et al. Reproductive performance and backflow study in cervical and post-cervical artificial insemination in sows. Animal Reproduction Science, v.136, n.12, p.14-22, 2012. Available from: <http://dx.doi.org/10.1016/j. anireprosci.2012.10.007>. Accessed: Nov. 12, 2019. doi: 10.1016/j. anireprosci.2012.10.007.

HERNÁNDEZ-CARAVACA, I. et al. Optimization of postcervical artificial insemination in gilts: Effect of cervical relaxation procedures and catheter type. Theriogenology, v.90, p.147-152, 2017. Available from: <https://doi.org/10.1016/j. theriogenology.2016.11.027>. Accessed: Nov. 12, 2019. doi: 10.1016/j.theriogenology.2016.11.027.

KAPELAŃSKI, W. et al. Morphometric characteristics of the reproductive system in Polish Large White and Polish Landrace gilts at $100 \mathrm{Kg}$ body weigh. Annals of Animal Science, v.13, n.1, p.45-53, 2013. Available from: <https://doi.org/10.2478/v10220012-0057-8>. Accessed: Feb. 15, 2020. doi: 10.2478/v10220-012$0057-8$

KNOX, R. V. Artificial insemination in pigs today. Theriogenology, v.85, n.1, p.83-93, 2016. Available from: <http://dx.doi. org/10.1016/j.theriogenology.2015.07.009. >. Accessed: Dec. 15, 2019. doi: 10.1016/j.theriogenology.2015.07.009.

KUMMER, R. et al. Is there difference on first farrowing performance of gilts mated at 1st, 2nd, 3rd or 4th oestrus? Acta Scientiae Veterinariae, v.33, n.2, p.125-130, 2005. Available from: <https://www.redalyc.org/pdf/2890/289021881004.pdf>. Accessed: May, 02, 2020.

LLAMAS-LÓPEZ, P. J. et al. A new device for deep cervical artificial insemination in gilts reduces the number of sperm per dose without impairing final reproductive performance. Journal of Animal Science and Biotechnology, v.10, n.1, p.11, 2019. Available from: <https://jasbsci.biomedcentral.com/ articles/10.1186/s40104-019-0313-1>. Accessed: May, 02, 2020. doi: https://doi.org/10.1186/s40104-019-0313-1.

MARTINEZ, E. et al. Minimum number of spermatozoa required for normal fertility after deep intrauterine insemination in nonsedated sows. Reproduction, v.123, n.1, p.163-170, 2002. Available from: <https://rep.bioscientifica.com/view/journals/ rep/123/1/163.xml>. Accessed: May, 07, 2020. doi: https://doi. org/10.1530/rep.0.1230163.

MELLAGI, A. P. G. et al. Bases fisiológicas e fatores que influenciam na puberdade da leitoa. In: F. E. W. Bortolozzo, I. (Ed.). Suinocultura em Ação: A fêmea suína de reposição. Porto Alegre: Palotti, v.3, 2006. p. 45-66.

MEZALIRA, A. et al. Influence of sperm cell dose and post-insemination backflow on reproductive performance of intrauterine inseminated sows. Reproduction in Domestic Animals, v.40, n.1, p.1-5, 2005. Available from: $<$ https://doi.org/1 0.1111/j.1439-0531.2004.00524.x>. Accessed: May, 07, 2020. doi: 10.1111/j.1439-0531.2004.00524.x.

PRUNIER, A. et al. Effects of age and live weight on the sexual development of gilts and boars fed two planes of nutrition. Reproduction Nutrition Développement, v.27, n.3, p.689700, 1987. Available from: <https://www.ncbi.nlm.nih.gov/ pubmed/3616130>. Accessed: May, 07, 2020. doi: 10.1051/ rnd:19870508.

RIESENBECK, A. Review on international trade with boar semen. Reproduction in Domestic Animals, v.46, p. 1-3, 2011. Available from: $\quad<$ https://doi.org/10.1111/j.1439-0531.2011.01869.x>. Accessed: May, 06, 2020. doi: 10.1111/j.1439-0531.2011.01869.x.

ROBINSON, J. J. et al. Traversing the ovine cervix-a challenge for cryopreserved semen and creative science. Animal, v.5, n.11, p.1791-1804, 2011. Available from: <https://www.ncbi.nlm.nih. gov/pubmed/22440420>. Accessed: May, 08, 2020. doi: 10.1017/ S1751731111000978 
ROCA, J. et al. Will AI in pigs become more efficient? Theriogenology,v.86,n.1,p.187-193,2016.Available from:<http:// dx.doi.org/10.1016/j.theriogenology.2015.11.026>. Accessed: Dec. 15, 2019. doi: 10.1016/j.theriogenology.2015.11.026.

ROZEBOOM, K. et al. The reproductive performance and factors affecting on-farm application of low-dose intrauterine deposit of semen in sows. Journal of Animal Science, v.82, n.7, p.2164-2168, 2004. Available from: <https://doi.org/10.2527/2004.8272164x>. Accessed: May, 04, 2020. doi: 10.2527/2004.8272164x.

SBARDELLA, P. et al. The post-cervical insemination does not impair the reproductive performance of primiparous sows Reproduction in Domestic Animals, v.49, n.1, p.59-64, 2014. Available from: <https://onlinelibrary.wiley.com/doi/full/10.1111/ rda.12224>. Accessed: May, 07, 2020. doi: 10.1111/rda.12224.

SERRET, C. et al. Intrauterine artificial insemination of swine with different sperm concentrations, parities, and methods for prediction of ovulation. Animal Reproduction, v.2, n.4, p.250-256, 2005. Available from: <http://www.cbra.org.br/pages/publicacoes/ animalreproduction/issues/download/Intrauterine\%20artificial. pdf $>$. Accessed: Jan. 20, 2020.

SOEDE, N. M. et al. Reproductive cycles in pigs. Animal Reproduction Science, v.124, n.3-4, p.251-258, 2011. Available from: <https://doi.org/10.1016/j.anireprosci.2011.02.025>. Accessed: May, 08, 2020. doi: 10.1016/j.anireprosci.2011.02.025.

SORIANO-ÚBEDA, C. et al. An overview of swine artificial insemination: retrospective, current and prospective aspects. Journal of Experimental and Applied Animal Sciences, v.1, p.67-97, 2013. Available from: <http://dx.doi.org/10.20454/jeaas.2013.709>. Accessed: Nov. 12, 2019. doi: 10.20454/jeaas.2013.709.

SUÁREZ-USBECK, A. et al. Post-cervical compared with cervical insemination in gilts: reproductive variable assessments. Animal Reproduction Science, v.211, p.106207, 2019. Available from: $<$ https://doi.org/10.1016/j.anireprosci.2019.106207>. Accessed: May, 02, 2020. doi: 10.1016/j.anireprosci.2019.106207.

TERNUS, E. et al. Reproductive performance of gilts submitted to post-cervical artificial insemination. Arquivo Brasileiro de
Medicina Veterinária e Zootecnia (Online), v.69, n.4, p.777784, 2017. Available from: <https://doi.org/10.1590/1678-41629285>. Accessed: Nov. 20, 2019. doi: 10.1590/1678-4162-9285.

TUMMARUK, P.; S. KESDANGSAKONWUT. Uterine size in replacement gilts associated with age, body weight, growth rate, and reproductive status. Czech Journal of Animal Science, v.59, p.511-518, 2014. Available from: $<$ https://www.agriculturejournals.cz/publicFiles/137217.pdf $>$. Accessed: Jan. 21, 2020.

ULGUIM, R. et al. Ovulation and fertility responses for sows receiving once daily boar exposure after weaning and OvuGel ${ }^{\mathbb{R}}$ followed by a single fixed time post cervical artificial insemination. Theriogenology, v.105, p.27-33, 2018a. Available from: $<$ https:// doi.org/10.1016/j.theriogenology.2017.09.005>. Accessed: Aug. 26, 2020. doi: 10.1016/j.theriogenology.2017.09.005.

ULGUIM, R. R. et al. Insertion of an intrauterine catheter for post-cervical artificial insemination in gilts: a case report. Semina: Ciências Agrárias, v.39, n.6, p.2833-2888, 2018b. Available from: <http://dx.doi.org/10.5433/16790359.2018v39n6p2833>. Accessed: Jan. 10, 2020. doi: 10.5433/1679-0359.2018v39n6p2833.

WABERSKI, D. et al. Application of preserved boar semen for artificial insemination: past, present and future challenges. Theriogenology, v.137, p.2-7, 2019. Available from: <https://www.sciencedirect.com/science/article/abs/pii/ S0093691X19301682?via\%3Dihub>. Accessed: Apr. 29, 2020. doi: 10.1016/j.theriogenology.2019.05.030.

WATSON, P.; J. BEHAN. Intrauterine insemination of sows with reduced sperm numbers: results of a commercially based field trial. Theriogenology, v.57, n.6, p.1683-1693, 2002. Available from: $<$ https://doi.org/10.1016/S0093-691X(02)00648-9>. Accessed: May, 06, 2020. doi: 10.1016/S0093-691X(02)00648-9.

WILL, K. J. et al. Reproductive performance in gilts following applications of different insemination doses and techniques. Theriogenology, v.160, p.26-32, 2021. Available from: <https:// doi.org/10.1016/j.theriogenology.2020.10.030>. Accessed: Nov. 23, 2020. doi: 10.1016/j.theriogenology.2020.10.030 